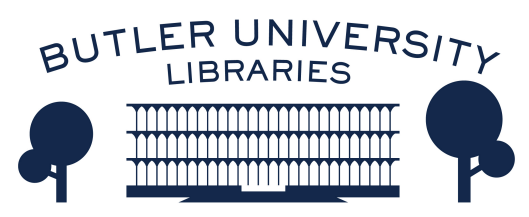

Journal of Hindu-Christian Studies

Volume 29 God and Evil in Hindu and Christian

Theology, Myth, and Practice

Article 4

2016

\title{
Reflections on God and Evil in the Krishna Bhakti Theology of Caitanya
}

Graham M. Schweig

Christopher Newport University

Follow this and additional works at: https://digitalcommons.butler.edu/jhcs

Part of the Hindu Studies Commons, and the Religious Thought, Theology and Philosophy of Religion Commons

\section{Recommended Citation}

Schweig, Graham M. (2016) "Reflections on God and Evil in the Krishna Bhakti Theology of Caitanya," Journal of Hindu-Christian Studies: Vol. 29, Article 4.

Available at: https://doi.org/10.7825/2164-6279.1627

The Journal of Hindu-Christian Studies is a publication of the Society for Hindu-Christian Studies. The digital version is made available by Digital Commons @ Butler University. For questions about the Journal or the Society, please contact cbauman@butler.edu. For more information about Digital Commons @ Butler University, please contact digitalscholarship@butler.edu. 


\title{
Reflections on God and Evil in the Krishna Bhakti Theology of Caitanya ${ }^{1}$
}

\author{
Graham M. Schweig \\ Christopher Newport University
}

\section{Prologue}

THE story that forms the short prologue at the start of Valmiki's Rāmāyana expresses something of how the bhakta deals with tragic loss and senseless violence. In the briefest of words, the story goes something like this: As Valmiki is performing his morning ablutions in the Tamasa River, he witnesses two cranes sweetly cooing at one another lovingly on a branch in a nearby tree. Suddenly, a hunter comes along and shoots an arrow through the chest of the male crane, who immediately drops to the ground. The female, herself alighting on the ground, sees her beloved mate writhing in agony with his mortal wound, and thus she begins to weep, drowning herself in the tears of her sorrow. Valmiki, upon seeing this senseless killing, in his anger curses the hunter from that day on to wander all the days of his life homelessly.

Who can mortally wound such an innocent loving creature? What kind of person does this? What kind of senseless act is this? Where is God in all this? Questions such as these are easily elicited from those who hear this story. We shall return to this story following a brief sketch of the relationship between God and evil in a bhakti theology.

\section{Theological Background for Bhakti}

In order to appreciate aspects of the relationship between God and evil in Bhakti traditions, specifically for the Krishna Bhakti tradition of Caitanya, we must apply at least some essential conceptions of the school's

Graham M. Schweig earned his doctorate in comparative religion from Harvard. He was a resident fellow at the Center for the Study of World Religions at Harvard. His scholarly specialization is the history and theology of Bhakti, the philosophy and history of Yoga, love mysticisms, and the comparative theology of religions. He was a Teaching Fellow at Harvard, a lecturer at University of North Carolina and Duke University, and was a Visiting Associate Professor of Sanskrit at the University of Virginia. He is currently Professor of Philosophy and Religion at Christopher Newport University, Virginia. Schweig has lectured widely in the US and in Europe, and has presented over three dozen invited lectures at the Smithsonian Institution in Washington, DC. He is author-translator of Bhagavad Gita: The Beloved Lord's Secret Love Song (Harper Collins, 2010), Dance of Divine Love: India's Classic Sacred Love Story (Princeton, 2005), and A Living Theology of Krishna Bhakti with Tamal Krishna Goswami (Oxford, NY, 2012). Forthcoming titles are The Rāsa Lìlā: Yoga of the Heart (Oxford, NY), The Bhakti Sutra: Narada's Concise Teachings on Divine Love and Bhagavad Gita Concordance: Comprehensive Word Reference (Columbia), and The Yoga Sūtra: Patanjali's Concise Teachings on Divine Union (Yale). Schweig is also a senior editor of the Journal of Vaishnava Studies. 
complex and richly nuanced theology to our topic. First, however, we must acknowledge at least briefly what we all know about the Hindu theological palette that undergirds this school's vision, before we can appreciate the school's theological portraiture.

With the conception of karma, there is no divine judgment but rather a system of justice built into the cosmic arrangement of things, thus making humans the utterly responsible agents for their good and bad actions and the resultant effects coming from them. Moreover, with the conception of samsāra, there is no impending dualistic eschatology that would include a permanent heaven or hell. Rather, the cycle of birth and rebirth is itself eternal unless and until humans attain mokșa or liberation from this cycle, at which point they are no longer subject to the painful dualistic experiences of this world. And thus Hans van Buitenen is able to make the claim that Hindus don't really experience tragedy as Western Abrahamic traditions do. Moreover, good and evil are not in competition with one another in India; they are consigned only to a small part of existence, namely this world of birth and rebirth, while supreme goodness prevails in all existence and in the ultimate state of things. It is perhaps important to underscore here that, for the Bhagavad Gitā, there is no pure darkness; rather there is ultimately only pure goodness or light, or viśuddha-sattva. Thus the theological backdrop of Bhakti traditions is essentially optimistic-the big picture, indeed, is ultimately goodness and light only.

\section{Theological Aspects of the Caitanya School}

At the foundation of Hindu theology is the conception of the ultimate as Brahman, the supreme reality, outside of which nothing exists and in which absolutely everything exists. of course the Vedantic advaitin and dvaitin schools of thought have their mahāvākya theological formulas that stand for their understanding of how this physical creation can exist when everything is spirit, or Brahman. The relationship of Brahman, the infinite world of spirit, to jagat, or the manifestation of the physical world, is certainly envisioned by 16 th century Caitanya school theologians as acintyaśakti, and carried further two centuries later by Baladeva Vidyābhūṣana as acintya-bhedābheda. This later more developed Vedantic formulation is expressive of the school's theological vision of God in relation to the world, indeed, a world that contains both good and evil: God is distinct from and completely separate from this world, on the one hand, and yet, simultaneously and thus inconceivably, God is utterly one with and inseparable from this world, on the other. Therefore we can deduce that the sufferings and the evils of this world participate, on some level, in the being of God, and not at all, however, in the being of God on other levels. This polymorphic theistic character of the divine is expressed well in the words of the Bhagavad Gìtā: "They worship me in my oneness (ekatva), in my separateness (prthaktva), and in my many forms facing everywhere (bahudā viśvatomukham)."

The Caitanya school of theology posits three irreducible categories of existence or divine energy, for nothing can exist outside of the being of the divine. The external dimension of the divine is called bahiranga-śakti, or literally "the outer realm of the divine energy," by this school's theologians, most notably by Jiva Gosvāmin, Rūpa Gosvāmin, and Krishnadāsa Kavirāja Gosvāmin in the sixteenth and seventeenth centuries. The internal dimension 
of the divine, or the divine realm, is called antaranga-śakti, or "the internal realm of divine energy." And the liminal dimension of the divine is called tatastha-śakti, or "the liminal realm of divine energy," referring to the eternal sentient beings. This physical world is mixed with a dual nature: the beautiful and the ugly, the wonderful and the treacherous, and the good and the evil, all belonging to the external energy of the divine. Whereas the internal energy of the divine is eternal existence made of pure spirit, pure awareness, and pure unbounded happiness. But perhaps most significantly and telling, is the placement of the sentient beings: in an area sandwiched between the external and internal realms. And finally, all three realms or dimensions originate, emanate from, and are eternally sustained by divinity, or God, who is understood as śaktimat, or "the one from whom these three energies emanate," and the one who himself is situated or located within the internal realm.

\section{Love is God}

The Krishna Bhakti theology of Caitanya has produced a conception of God that amounts to (my bulky phrase) a polymorphic trimonotheism. First, we must acknowledge that the Hindu background of this Bhakti tradition accepts the idea that God has unlimited forms, ananta-rūpa. But this tradition asserts that among the innumerable unlimited divine forms-the polymorphic character of the godhead, as it were-it is Śrī Krishna who is himself the highest. However, Śrī Krishna, the bhagavat, the saktimat, sees his own ultimate object of worship, his own greatest love, as his beloved counterpart, Śrī Rādhā, the essence of all śaktis.
But it doesn't stop there. The divine love that is exchanged between Śrī Rādhā and Śrī Krishna in their līlās or divine acts becomes itself the greatest aspect of the godhead, for it is the power of this love between them that subsumes them both. For this tradition, the theistic whole is greater than the sum of its two supreme divine parts or persons. This supremely powerful fullness of love between Śrī Rādhā and Śrī Krishna is worshipped by the tradition in the person of Śri Caitanya who is himself understood as the very embodiment of the love exchanged between the two supremely divine lovers. The ultimate formation of the divine as a tri-monotheism consists of these three personages: Śrī Krishna, Śrī Rādhā, and Śrī Caitanya.

It must be underscored that this tradition worships Love supreme. This is a tradition that certainly worships God, but not only God. It certainly worships the supreme Goddess, Rādhā, but not only the Goddess. The ultimate focal point of worship is the love transacted between them, as it is this greatest love that subsumes them both, and thus is itself the ultimate aspect of the realm in which the supreme masculine and supreme feminine personages of the godhead eternally engage. In conclusion, this tradition worships a divine relation over and above a divine person or the two divine persons subsumed by it, and thus it is not just that God is love, but Love is God-it is in this singular sense that we can speak of it as a monotheism.

\section{Darkness and Evil in Relation to Love}

Krishna in the Bhagavad Gitā unequivocally declares, "Vāsudeva is everything!" If nothing can exist outside of Krishna, then surely everything, including evil, exists within Krishna. And yet, in a theology of Krishna bhakti, within 
the "everything" three distinct phases of the divine can be observed, each of which has a greater or lesser relation or connection to evil and the realm of darkness: (1) the supreme person of the divine (paramam purusam divyam or the bhagavat), (2) the presence of the divine (viśva-rūpa, brahman, and purusa), and (3) the descent of the divine (avatāra, pūrṇāvatāra, and arcāvatāra).

The supreme person stands far beyond this world in a realm that is totally other, in a transcendent realm that is purely nonphysical. The divine beloved stands within his lïlā, or divine "acts," in his spiritual world, dhāma, in loving relation to other divine personages, rasa. This transcendent realm of the divine beloved is utterly untouched by evil, for it is the realm fully permeated with divine love. Yet it is from this realm that Krishna forever beckons souls to leave a world of darkness and to come to him in his perfect world. It is from this realm that Krishna yearns for souls and calls them to his divine heart. And thus the unique and most outstanding feature of Krishna is his playing the flute, the music with which he is forever calling souls to come to his perfect realm that is filled with all that is splendidly beautiful, playful, and delightful.

The divinity, furthermore, can reveal parts of these unmanifested lilās to persons in this world through a divine descent, or avatāra. Not only are parts of the transcendent unmanifested acts of divinity revealed to humans in this world through a divine descent, but the divine descent includes an added dimension to these acts or lìlās that is not present in the unmanifested acts: the vanquishing of evil and evil persons and forces in this world. Krishna boldly announces the following words in the Bhagavad Gitā:
Indeed, whenever there is

a decline of dharma,

O Bhārata,

And an emerging

of what opposes dharma-

at that time I send forth my Self.

For protection of the virtuous

and for destruction of evil acts,

For the purpose of establishing dharma,

I become fully manifest age after age. ${ }^{4}$

Indeed, the various lì $\bar{a} s$ that Krishna manifests during his descents to this world include divine dramas of the punishing and even killing of demonic beings and creatures.

The divine descent of God or the divine takes yet another powerful form. There, standing together in just about every temple of the Krishna bhakti tradition, are the figures of Krishna with his supremely beloved Rādhā, gazing out at souls while Krishna is sounding the flute, ever beckoning souls to come to them, to join them, calling us to abandon all the evils of this world and to bring to this world their divine love, to fill it up more and more with this love. The arcāvatāra, then, is yet another form of God as divine descent, an extension of God to this world as the divine beloved.

Darkness and evil in this theological scheme of things is most directly observable in the various ways divinity manifests its presence in revelations of the worldly superlatives (viśvarūpa), in the total spiritual embrace of the divine as Brahman, and it the indwelling presence of the divine in the heart of all living beings and at the core of all cosmic existences (purușa). It would seem, and correctly but not completely so, that the realm of divine love is far away and above the evils of this world. Yet God as a divine beloved, as we have seen, nevertheless sends out 
a love call, a call to souls for their love, by the sounding of Krishna's flute, a personal attribute for which Krishna is so well known.

\section{A Total World Process as Part of the Divine}

An important and exceptional form of God as divine presence that displays how God ultimately contains everything in this world, all that is good and all that is evil in a total inexplicable world process, is Krishna's revelation of his viśva-rūpa as described in the Eleventh Chapter of the Bhagavad Gitā. It is merely individual or personal karma-it is not just the individual accrual of pappa or punyarather, it is a collective phenomenon, a total world process that points rather to the big picture, in which all beings participate beyond their comprehension but with the faith that there is some greater purpose at work here. There are reasons for all unfortunate things that can occur in life, on individual and massive scales, for all the evils inflicted on humans by humans that go beyond mere cause-and-effect.

Krishna's secret teaching in relation to the battle scene in which Arjuna finds himself perhaps provides these events that seem to elude merely karmic occurences. Beyond all Arjuna's ethical reasoning and comprehension expressed in the first chapter of the Bhagavad Gìtā, Krishna bestows upon Arjuna special eyes to see the armies of men march into the mouths of the magnificent but terrifying forms of Krishna's viśva-rūpa, a divine form of God that engulfs and contains everything in a totalworld-process:

Behold my forms,

O Pārtha,

by the hundreds, or by the thousands-

Divine, of various types, and of various colors

and appearances.

Before you, in one place, behold now the entire universe, with every moving and nonmoving being

Within my body, o Gudākesha, and whatever else you desire to see. ${ }^{5}$

Sanjaya, the narrator of the Bhagavad Gitā's conversation, describes in the following words the cosmic process to which this fatal battle is connected:

As moths, with great velocity,

Enter a blazing fire unto their destruction,

Similarly, the worlds also

Enter your mouths with great velocity, unto their destruction. ${ }^{6}$

Again, Krishna's following words reveal that the warriors on the battlefield of Kurukshetra are fated to die, whether Arjuna participates in this process or not:

The Beloved Lord said:

Time I am, acting to destroy the worlds, advancing forward

To completely annihilate the worlds here, ever turning forward.

Even without you [acting], they shall all cease to be- 
Those who are warriors

arrayed on the opposing side. ${ }^{7}$

This total-world-process about which we have been speaking, then, appears to be a process that reaches up to a cosmic level that also includes and accounts for the particular individuals involved collectively. It is not merely a cosmic purpose that is enacted in a disaster or devastating war, nor is it merely a karmic purpose in the typical sense. The viśva-rūpa appears to enact a powerful and fated event, which must occur to satisfy a grand cosmic and individual karmic scheme that is beyond human comprehension but can be appreciated as ultimately purposeful, an event that is tied in to the "big picture."

Events such as massive earthquakes that take the lives of many thousands of humans at once, or the massive killings of war, or the sinking of a ship or the crashing of a planewhatever the catastrophic event that appears to entail the indiscriminate suffering and death of a massive number of persons of any age or station of life is shown and acknowledged by Krishna in the Eleventh Chapter of the Bhagavad Gìtā as part of a total world process that is ordained and contained within the divine. On the one hand, it becomes closer to a cosmic event that might be associated with the forces of destruction or even cosmic dissolution, a realm for which the deity of Śiva is so well known. And yet such events of massive destruction in this world seem too small for Siva's role in charge of cosmic dissolution, while the laws of karma are more individually determined and created, on the other hand. What I am suggesting here is that there is a total world process that does not exclude the greater cosmic process nor does it exclude the individual karmic process. Indeed, such a total world process includes both, incorporates both, and yet accomplishes something apart from both. Massive wars arising from evil, on an ostensive level, can participate in this very total world process, at a more hidden level, at the same time.

\section{Concluding Reflections}

of course it is impossible to treat the topic of God and evil in a Bhakti theology in any sort of thoroughgoing presentation in such a short space, and especially to also examine it comparatively in relation to Christian traditions. But let me bring out here that what is at the root of the Caitanya school's theology of love is a vision of freedom. It is not within the scope of this talk to understand the Bhakti conception of free will versus the conditioned state of the self. And further, more can be shown how the darkness of this world, how the evils of this world, are epiphenomenal in relation to the very soil in which love must thrive and grow, the soil of freedom. Love cannot be threatened, it cannot be forced, it cannot be manipulated or controlled, and it cannot be bartered nor can it be judged-freedom is the precious soil that allows the heart to blossom. Therefore freedom necessitates the possibility of evil so as to not eclipse an uncompromised, total freedom that can give way to the highest love, the pure love of prema-bhakti most naturally. It must come freely, eventually, from a heart that can choose (as is represented by the liminal metaphysical position of living beings as tatastha-śakti) to act either from dark places or to act out of the purity of heart. But by the grace of the guru, one can achieve this purity of heart and the freedom from the strictures of a conditioned existence in this present life. 
Evil, then, in a sense is an expression of that freedom with which we are all ultimately endowed, a freedom that also paves the way for pure love. It is the price we as humans must all pay in this total world process, one way or another. At times, humans become the unwitting martyrs who sacrifice their lives at the hands of evildoers, who commit acts that can seem utterly senseless. Yet, at the same time, such martyrdom is supposed to make sense out of senseless evil because they pay the price for the freedom that can yield pure love, premabhakti.

Of course, the Caitanya school does not have a God who empathically shares in the suffering of humankind, who himself descends to suffer long and die a miserable death at the hands of evil. To my mind, this is unique to the Christian traditions. At best, the bhaktas of this world develop a passion for love of God as the divine beloved, and also develops a loving compassion for souls whose hearts are steeped in suffering. And in addition to the ways passion and compassion function in bhakti, there is a third element in the bhakta that relates to evil: the offering of one's whole heart to all in this world as well as to the divine in the form of art, poetry, drama, and music as a way to bring into a very mixed and troubled world that which is truly beautiful and loving.

\section{Epilogue}

Let us return to the Rāmāyana's sad story recounted earlier. Valmiki's anger at the evil act of the hunter produced a curse that I had not appreciated until recently, when I looked at it in light of the phenomenon of terrorism: Why did the sage Valmiki curse the hunter to wander all the days of his life homelessly? The curse was designed to respond to the living, rather than to the dead. After all, the goal of evil in terrorism is not merely to kill persons, but rather to destroy the quality of life for the living. Valmiki, I'm sure, felt so sad for the dying male crane. But his curse was designed to acknowledge or correspond to how the female crane would be unable to find any kind of home ever again on any branch in any tree, precisely because she will associate any branch in any tree with the painful and tragic loss of her beloved mate, for such places will be forever vulnerable to the suffering and loss caused by the hunter's cruelty.

And finally, as we know, Valmiki's anger toward the hunter and his compassion for the living female crane produced an "angry curse" transformed by "poetic verse." This is also quite telling. His soka became transformed into his sloka, which inspired the basic metrical form of verse and its contents for the Rāmāyana. Thus evil in this world, for the bhakta, becomes the very dark background out of which all that is to be lifted up as beautiful, playful, and delightful in God's being. Such darkness can form the starkly contrasting backdrop of all things in this world that reveal to whatever greater or lesser degree the powerful sparks of light coming from the divine. Perhaps one purpose of evil in this world that is highlighted by this theology of Krishna bhakti is unintended capacity and result of darkness to enhance, to light up and to lift up all that is good in the world that is reflective of even just a modicum of God's supreme beauty, his playfulness, and his love. 
20 Graham M. Schweig

\section{Notes}

${ }^{1}$ This article is an expanded and partially modified version of the talk entitled, "From 'Angry Curse' to 'Poetic Verse': Aspects of Good and Evil in Bhakti Texts and Traditions," as part of the session entitled "God and Evil in Hindu and Christian Theology, Myth, and Practice," originally presented at the Society for Hindu-Christian Studies meeting at the international meeting of the American Academy of Religion in Atlanta, Georgia, on November 21, 2015.

${ }^{2}$ Bhagavad Gìtā, Chapter 9, Verse 15, from Bhagavad Gitā: The Beloved Lord's Secret Love Song, trans. by Graham M. Schweig (New York: Harper Collins, 2010). Subsequent verse translations from the Bhagavad Gìtā quoted in this article are taken from this edition.

${ }^{3}$ Bhagavad Gìtā, Chapter 7, Verse 19.

${ }^{4}$ Bhagavad Gìtā, Chapter 4, Verses 7 and 8.

${ }^{5}$ Bhagavad Gìtā, Chapter 11, Verses 5 and 7.

${ }^{6}$ Bhagavad Gìtā, Chapter 11, Verse 29.

${ }^{7}$ Bhagavad Gìtā, Chapter 11, Verse 32. 